\title{
Evaluation of Antidiabetic Activity of Aqueous Extract of Leaves from Phragmanthera capitata (Sprengel) S. Balle (Laurenthaceae) in Wistar Albino Rats
}

\author{
Cesaire Feudjio, Guy Sedar Singor Njateng ${ }^{*}$, Jules-Roger Kuiate* \\ Laboratory of Microbiology and Antimicrobial Substances, Department of Biochemistry, Faculty of Science, University of Dschang, \\ Dschang, Cameroon
}

Email address:

cesairebio@yahoo.fr (Cesaire F.), njatguysedars@yahoo.fr (Guy S. S. N.), jrkuiate@yahoo.com (Jules-Roger K.)

${ }^{*}$ Corresponding author

To cite this article:

Cesaire Feudjio, Guy Sedar Singor Njateng, Jules-Roger Kuiate. Evaluation of Antidiabetic Activity of Aqueous Extract of Leaves from Phragmanthera capitata (Sprengel) S. Balle (Laurenthaceae) in Wistar Albino Rats. Journal of Diseases and Medicinal Plants.

Vol. 4, No. 4, 2018, pp. 96-109. doi: 10.11648/j.jdmp.20180404.11

Received: August 23, 2018; Accepted: September 9, 2018; Published: November 9, 2018

\begin{abstract}
Diabetes mellitus is a public health problem affecting about $8.4 \%$ of people in the world and knows an alarming progression in sub-Saharan Africa and in Cameroon precisely. The current therapeutic strategies have prohibitive prices, are unavailable and have harmful side-effects. So, this work aimed at contributing to the valorization of medicinal flora and 'knowledge of traditional healers in Foumban, West-Cameroon, in the treatment of diabetes. An ethnopharmacological survey was conducted by consulting traditional healers of the District of Foumban. At the end of this investigation, Phragmanthera capitata, which was found to be the most active plant following preliminary tests, was selected for antidiabetic studies on three groups of rats: normal glycaemia, temporary hyperglycemia and diabetic. The first two groups were treated per os, with aqueous extract of leaves from P. capitata, with the doses of $\mathrm{D} 2(4 \mathrm{~mL} / \mathrm{kg})$ obtained from the traditional healers, D1 (half of D2), D3 (double of D2) and by glibenclamide $(2.5 \mathrm{mg} / \mathrm{kg}$ ). The rats of the last group were treated twice per day, with the same doses of extract and glibenclamide for 13 days and were sacrificed on the 14th day. Their blood was collected by cardiac puncture for the determination of biochemical and hematological parameters. Phytochemical screening was performed using standard methods. The administration of aqueous extract of $P$. capitata led to a hypoglycaemia effect in normal rats, a reduction of glycaemia in the temporary hyperglycaemia and diabetic rats. In addition, an improvement of lipid assessment, renal and hepatic parameters related to the installation of diabetes, as well as an immune-modulator effect of the extract were noted in diabetic rats treated for 13 days. Phytochemical screening indicated that the extract contains saponins, tannins, flavonoids, steroids and terpens. This work along with findings justifies the traditional use of this plant in the treatment of diabetes mellitus.
\end{abstract}

Keywords: Diabetes, Ethnopharmacologic Survey, Phragmanthera capitata, Biochemical Parameters, Hematologic Parameters

\section{Introduction}

Diabetes formerly considered as an uncommon illness in sub-Saharan Africa became public health problem and knows an alarming progression [1]. According to the estimates, more than 21 million $(5 \%)$ people were suffering from diabetes in 2014 and more than 41 million diabetics are expected in 2035 [1]. In Cameroon, the prevalence of diabetes rose from $1.5 \%$ in 1990 to $10 \%$ in 2014 and an increase of $80 \%$ is expected by 2035 [2]. The socio-economic impact of diabetes is very important in most countries of subSaharan Africa and generates enormous health expenditures which do not cease growing. Diabetes and its consequences caused 481.000 deaths in Africa, of which 13.822 in Cameroon in 2014; $75 \%$ of these deaths occurred among people of less than 60 years old with a strong rate in the young people from 20 to 39 years old [3]. The burden of diseases related to diabetes and the reduction of the life 
expectancy which results from this will in general slow down the economic growth of sub-Saharan Africa and the emergence of Cameroon in particular $[4,5]$.

The treatment consists of the insulin injection (diabetes of the type 1) or the administration of oral antidiabetics (type 2 diabetes) [6, 7]. The oral antidiabetics result in the standardisation of the glycaemia in less than $50 \%$ of cases. They do not have regressive effects on the established lesions and are not indicated in case of renal and hepatic insufficiencies as well as during pregnancy [7]. The cost of the treatment is considerable and is estimated at 108.9 USD per month in Cameroon [1]. Insulin capsule currently costs 3000 FCFA in Cameroon. The people suffering from diabetes and their family support almost the entire cost of the medical care [3]. Moreover, the supply in the population's drugs, the infrastructures and medical staff are insufficient [8]. Plants constitute a medical potential not only available at lower costs for the populations, but is also less toxic $[9,10]$. Unfortunately, there are not enough scientific data on their effectiveness and harmlessness, making doubt of the effective role of these medicinal plants on diseases in general and diabetes in particular [2].

In addition, today, the knowledge of traditional healers is less transmitted and tends to disappear [11]. A simple manner to preserve the cultures, the knowledge and the plants which are dependent consists of developing this knowledge, test them to check and to validate their supposed effects and finally to valorize by integrating traditional medicine in the modern health care system $[11,12]$. This work which falls under this strategy of WHO for traditional medicine aims at contributing to the valorization of medicinal flora and knowledge of traditional healers of the district of Foumban, West-Cameroon, in the treatment of diabetes.

\section{Materials and Methods}

\subsection{Ethnopharmacological Survey}

\subsubsection{Description of the Area of Investigation}

The ethnobotanical survey was conducted in three villages of the district of Foumban (Njissé, Njimbam I and Njimbam II), in the region of West-Cameroon. The district of Foumban covering a surface of approximately $418 \mathrm{~km}^{2}$, is located between $5^{\circ} 43^{\prime}$ and $5^{\circ} 43^{\prime}$ Northern latitude and the $10^{\circ} 53^{\prime}$ $10^{\circ} 55^{\prime}$ of East longitude. The town of Foumban is the headquarters of Noun division and of the royal palace of Bamoun people [13]. This latter uses medicinal plant for its primary healthcare. In this area, traditional healers are famous to have a good knowledge on the use of medicinal herbs [13].

\subsubsection{Data Collection}

The ethnopharmacological investigation was conducted from July 15th, 2015 to October 17th, 2015 and included 27 traditional healers (Table 1). The data were collected through a semi-structured questionnaire making it possible to evaluate the knowledge about the disease and the plant, its use, the mode of preparation and the regulation recommended by each questioned traditional healer. The traditional healers were also questioned on the means by which they lay out to diagnose the disease as well as the alternative measures in the event of failure of their treatment. The investigation was conducted in Bamoun language with the assistance of a local guide after obtaining the enlightened assent of the healers.

The collected data were registered in a Microsoft Excel worksheet. The value of use [14], a method of quantification which shows the relative importance of a plant species, was calculated according to the following formula: $U V=(n / N) x$ 100 , where $\mathrm{UV}=$ value of use of a species, $\mathrm{n}=$ number of quotation of a species and $\mathrm{N}=$ full number of quotation. Following the application of this formula, the value of use of Phragmanthera capitata was found to be the highest and no study on its antidiabetic properties was found; reason why that plant was selected for thorough antidiabetic studies.

Table 1. Distribution of the healers questioned in the villages of the study area.

\begin{tabular}{lll}
\hline Villages & $\begin{array}{l}\text { Number of healers } \\
\text { questioned }\end{array}$ & $\begin{array}{l}\text { Number of plants } \\
\text { (receipts) listed }\end{array}$ \\
\hline Njissé & 11 & 16 \\
Djimbam I & 8 & 11 \\
Djimbam II & 8 & 8 \\
Total & 27 & 35 \\
\hline
\end{tabular}

The listed plants were collected under the supervision of the traditional healers and were authenticated at the national herbarium of Cameroon by comparison with a reference sample preserved at the herbarium.

\subsection{Evaluation of the Antidiabetic Properties of Phragmanthera Capitata}

\subsubsection{Preparation of the Extract and Doses of Phragmanthera Capitata}

Phragmanthera capitata was collected from an avocado tree in February 2016. After harvest, the leaves were separated from the stem, then weighed and washed. The aqueous extract of the leaves of Phragmanthera capitata was prepared according to the instructions of the traditional healers by decoction in the following way: $125 \mathrm{~g}$ of well washed fresh leaves were added to $0.5 \mathrm{~L}$ of distilled water. The mixture was boilled during $15 \mathrm{~min}$. After 30 minutes of cooling, the obtained solution was then filtered, to give approximately $250 \mathrm{~mL}$ of extract of greenish color. By considering this volume for a person of $70 \mathrm{~kg}$ (dose of the traditional healers), the dose of $4 \mathrm{~mL} / \mathrm{kg}$ (D2) of body weight was administered to a group of rats. On the basis of this amount, the double amount of the traditional healers (D3) and the half of the amount (D1) were administered to two other groups of rats.

\subsubsection{Breeding and Preparation of the Experimental Animals}

The experimental animals were young albino rats (Rattus norvegicus) of Wistar variety and of both sexes. They were 3 to 4 months old and having an average weight of 
$182,666 \pm 21,960 \mathrm{~g}$. They were obtained by breeding for 4 months at the animal house of the University of Dschang. The rats were randomly assigned to groups. The animals had free access to water and food whose composition was previously described [15].

\subsubsection{Induction of Diabetes}

Permanent diabetes mellitus was induced by intraperitoneal injection of single dose of alloxan monohydrate $(150 \mathrm{mg} / \mathrm{kg})$ [16], to one night fasting rats. For this purpose, the aqueous solution of alloxan was prepared right before the injection. After injection of the solution of alloxan, the rats had free access to food and a diluted solution of glucose during one night in order to avoid the hypoglycemic shock. Three days after injection of the alloxan, the establishment of diabetes mellitus in rats was verifed by the measurement of the glycaemia. The animals having presented a glycaemia higher than $333 \mathrm{mg} / \mathrm{L}$ were in permanent hyperglycaemia [17] and were selected for the continuation of work.

\subsubsection{Effect of Aqueous Extract of Phragmanthera Capitata in the Normal Glycaemia Rats}

In order to check the assertion of the healers according to which Phragmanthera capitata can be consumed without risk by a normal subject, five batches of 5 rats each, after fasting for 18 hours were randomly constituted and treated as follows:

-The rats of batch 1, negative control received distilled water $(10 \mathrm{ml} / \mathrm{kg})$;

-The rats of batch 2 , positive control received in single administration, the solution of glibenclamide (2.5 $\mathrm{mg} / \mathrm{kg}$ );

-The rats of batches 3,4 and 5 received in single administration, respectively the doses D1, D2 and D3 of the aqueous extract of $P$. capitata. Before administration of the test substances, the basic glycaemia of each rat was determined. After administration of the test substances in single amount, blood samples were collected at an interval of 1 hour within a period of 4 hours [17] in order to determine glycaemia.

\subsubsection{Effect of Aqueous Extract of Phragmanthera Capitata in Temporary Hyperglycaemia Rats}

To determine the capacity of extract to reduce post prandial glycaemia, 5 batches of 5 rats (male and female) each was randomly made up. At time t-30 $\mathrm{min}$ (30 $\mathrm{min}$ before the administration of the overload of glucose), blood sample was collected in order to measure the basic glycaemia. The rats were then cramed:

-With distilled water $(10 \mathrm{ml} / \mathrm{kg})$ for batch 1 , the negative control;

-With a solution of glibenclamide ( $2.5 \mathrm{mg} / \mathrm{kg})$ for batch 2 , positive control;

-With the aqueous extract of Phragmanthera capitata, D1, D2 and D3 $(4 \mathrm{~mL} / \mathrm{kg})$ respectively for the rats of batches $3,4,5$.

Blood samples were collected at an interval of $30 \mathrm{~min}$ within a period of 4 hours in order to determine the glucose level in each sample.

\subsubsection{Effect of Aqueous Extract of Phragmanthera Capitata in the Diabetic Rats}

In order to determine the antidiabetic activity of the extract, six batches of 5 rats (male and female) each were randomly constituted and the animals were treated by cramming each morning at $8 \mathrm{AM}$ and the evening at $6 \mathrm{PM}$ during 14 days:

-The rats of batch 1 , neutral control (not diabetic) and those of batch 2, negative control received distilled water $(10 \mathrm{ml} / \mathrm{kg})$;

-The rats of batch 3, positive control received a solution of glibenclamide $(2.5 \mathrm{mg} / \mathrm{kg})$;

-Those of batches 4, 5 and 6 respectively received D1, D2 and D3 doses.

Treatment was stopped on the 7 th day after the return of glycaemia to normal and continued again on the 8th day. Blood samples for the determination of glycaemia were collected at an interval of 1 hour within a period of 5 hours on the first day of treatment, then every day (twice a day) within the first week and finally every two days until the 14th day.

\subsubsection{Determination of the Glycaemia Level}

Glycaemia was measured by a single drop of blood obtained from the caudal end of the animals (venous blood) using a glucometer with reactive strips (Accu Check Active) Rock manufactured in April 2016 and of batch number 24649031. This drop of blood obtained by puncture of the tail after excision was deposited on the active zone of a strip. The reading of the glycaemia was made automatically 5 seconds after and the result expressed in $\mathrm{mg} / \mathrm{dL}$ of blood.

\subsubsection{Determination of Some Hematological and Biochemical Parameters}

\section{i. Blood Sample Collection}

On the last day of the cramming, the animals were subjected to 12 hours fasting (food and water), after what the animals were anaesthetized by the chloroform vapors and dissected. The blood of each animal was collected by cardiac puncture using a syringe and put in two tubes of which one with anticoagulant (EDTA) and the other without anticoagulant. The blood contained in EDTA tubes was used directly for the determination of the hematological parameters. The blood collected in the tubes without anticoagulant was left at rest during 3 hours in ice-cold water then centrifuged at $3000 \mathrm{~g}$ during $20 \mathrm{~min}$. The obtained supernatant (serum) was collected using a micropipette, transferred in the labelled eppendorf tubes and stored at $30^{\circ} \mathrm{C}$ until the moment of the determination of the biochemical parameters [15].

\section{ii. Determination of Hematological Parameters}

The hematological parameters were mesured using an impedance Coulter automat. 


\section{iii. Determination of the Biochemical Parameters}

Serum parameters namely total cholesterol, total triglycerides, total proteins, creatinine, urea, Glutamate Oxolo-acetate transaminase (ASAT) and Glutamate Pyruvate transaminase (ALAT) were measured by enzymatic methods using commercial kits TECO DIAGNOSTICS (USA) for the first 5 parameters and Points Scientific (Belgium) for the last 2 parameters as described by the manufacturer. This was done using a spectrophotometer of Genesys brand.

\subsection{Phytochemical Analysis of the Crude Extract of Phragmanthera Capitata}

The phytochemical characterization of the extract was performed based on standard methods [18].

\subsection{Statistical Analysis}

The values of the parameters were expressed as average \pm standard error to average. After variance analysis (ANOVA and ANCOVER), comparison of averages between various batches of rats was carried out based on the test of WallerDuncan using SPSS software version 20.0. Values of $\mathrm{p}<0.05$ were considered statistically significant.

\section{Results}

\subsection{Ethnopharmacological Investigation}

\subsubsection{Demographic Characteristics of Healers, Perceptions} About Causes and Symptoms of Diabetes

27 traditional healers, of male $(89 \%)$ and female (11\%) sexes, from 45 to 85 years old and illiterates for the majority $(93 \%)$ were surveyed. They were of Moslem confession $(100 \%)$.

Most healers (96\%) used the term «ya'a chouka'a» (disease of sugar) to qualify the diabetes. According to the latter, " ya'a chouka'a » appears in children at low age (4\%), in overweight persons $(80 \%)$ and mystically in other persons $(6 \%)$. Other healers $(11 \%)$ think that the exaggerated consumption of food such as corn fufu and palm oil favours the disease. The latter recommend their patients to avoid this food during the treatment. The questioned traditional healers use the following indications to diagnose the disease: abundant emission of urines, foaming and yellow color $(61 \%)$, an intense thirst (16\%), urine of diabetics attracts ants because of the sugar it contains (8\%). Finally, others $(15 \%)$ refer to the diagnoses of doctors and require a control of sugar rate at the hospital during treatment.

\subsubsection{Principal Information Collected During the Ethnopharmacological Investigation}

The species of listed plants gathered by families is presented in Table 2. It appears that 35 species of plants belonging to 25 botanical families are used by the healers of Foumban for the treatment of diabetes. Tree families contain more than two species of listed plants: Asteraceae (14.81), Apiaceae (11.11), Myrtaceae (7.41) and Zingiberaceae (7.41). Among the listed species, 5 are used in mixture and the 30 others are used alone. The most represented species used alone are: Allium sativium (8.57), Aloe barbadensis (8.57), Phragmanthera capitata (8.57), Allium cepa (5.71), Mangifera indica (5.71), Catharenthus roseus (5.71), Vernonia amygdalina (5.71), Persea americana (5.71) and Eucalyptus globulus (5.71). The posology varies from 1 to 3 glasses per day in 1 to 3 times. The route of administration indicated by the healers is oral. The parts of the plant used in the various preparations are variable and are used in a fresh or dry state. The listed modes of preparation are: decoction, maceration, the infusion and powder. These various modes often depend on the part of the plant used, but the frequencies in the ethnopharmacological uses are variable.

Table 2. Principal information collected during the ethnopharmacological investigation of plants used in the district of Foumban for the treatment of diabetes mellitus.

\begin{tabular}{|c|c|c|c|c|c|c|c|}
\hline $\begin{array}{l}\text { Family of } \\
\text { plant }\end{array}$ & $\begin{array}{l}\text { Scientific } \\
\text { name }\end{array}$ & $\mathbf{n}$ & $\begin{array}{l}\text { Vernacular name } \\
\text { (common name) }\end{array}$ & $\begin{array}{l}\text { Associated } \\
\text { plants }\end{array}$ & Preparation & $\begin{array}{l}\text { Posology for an adult } \\
\text { of } 70 \mathrm{~kg}\end{array}$ & Authentification \\
\hline Alliaceae & Allium cepa $\mathrm{L}$. & 2 & $\begin{array}{l}\text { Kaah (Onion of the } \\
\text { village) }\end{array}$ & Lemon & $\begin{array}{l}\text { Slice } 3 \text { large onions. } \\
\text { Boil within a period of } \\
10 \text { min in } 1 \text { liter of } \\
\text { water. }\end{array}$ & $\begin{array}{l}1 \text { glass in the morning } \\
1 \text { glass at midday } \\
1 \text { glass in the evening. }\end{array}$ & $\begin{array}{l}\text { C: Westphal No } 10091 \\
\mathrm{H}: 42791 / \mathrm{HNC}\end{array}$ \\
\hline Aloaceae & $\begin{array}{l}\text { Aloe } \\
\text { barbadensis }\end{array}$ & 3 & (Alovera) & / & $\begin{array}{l}\text { Put } 3 \text { leaves in } 1 \text { liter of } \\
\text { water within a duration } \\
\text { of } 30 \text { minutes }\end{array}$ & $\begin{array}{l}1 \text { glass in the morning } \\
1 \text { glass at midday } \\
1 \text { glass in the evening. }\end{array}$ & $\begin{array}{l}\text { C: Dang D. No } 124 \\
\text { H: } 18676 / S R F-C A M\end{array}$ \\
\hline Anacardiaceae & $\begin{array}{l}\text { Mangifera } \\
\text { indica } \mathrm{L} \text {. }\end{array}$ & 2 & $\begin{array}{l}\text { Chim mango } \\
\text { (Mango tree) }\end{array}$ & / & $\begin{array}{l}1 \text { handful in } 1 \text { liter of } \\
\text { water and boil within a } \\
\text { period of } 15 \text { minutes }\end{array}$ & $\begin{array}{l}1 \text { glass in the morning } \\
1 \text { glass at midday } \\
1 \text { glass in the evening. }\end{array}$ & $\begin{array}{l}\text { C: Dang D. N } 104 \\
\text { H: } 18646 / S R F-C A M\end{array}$ \\
\hline Annonaceae & $\begin{array}{l}\text { Annona } \\
\text { muricata L. }\end{array}$ & 1 & $\begin{array}{l}\text { Choua-choua } \\
\text { (corossolier) }\end{array}$ & / & $\begin{array}{l}1 \text { handful in } 2 \text { liters of } \\
\text { water and boil }\end{array}$ & $\begin{array}{l}1 \text { glass in the morning } \\
1 \text { glass in the evening. }\end{array}$ & $\begin{array}{l}\text { C: Dang N N } 162 \\
\text { H: } 18681 / \text { SRF-CAM }\end{array}$ \\
\hline \multirow{3}{*}{ Apiaceae } & $\begin{array}{l}\text { Centella } \\
\text { asiatica }(\mathrm{L}) \\
\text { Urb. }\end{array}$ & 1 & $\begin{array}{l}\text { (violette marron or } \\
\text { cochlearia) }\end{array}$ & $\begin{array}{l}\text { Costus } \\
\text { lucanusianus }\end{array}$ & $\begin{array}{l}\text { Boil } 1 \text { handful of leaves } \\
\text { in } 2 \text { liters of water }\end{array}$ & $\begin{array}{l}1 \text { glass in the morning } \\
1 \text { glass at midday } \\
1 \text { glass in the evening. }\end{array}$ & $\begin{array}{l}\text { C: Letouzey R. } N^{\circ} \\
5667 \\
\text { H: } 742 / \text { SRF-CAM }\end{array}$ \\
\hline & Daucus carota & 1 & Carrot & / & Consume like vegetable & At will & $\begin{array}{l}\text { C: Dang N }{ }^{\circ} 514 \\
\mathrm{H}: 25579 / \mathrm{HNC}\end{array}$ \\
\hline & $\begin{array}{l}\text { Petroselinum } \\
\text { crispum } \text { Nym. } \\
\text { Catharanthus } \\
\text { roseus (L) G. }\end{array}$ & 1 & $\begin{array}{l}\text { (parsley) } \\
\text { (Periwinkle of } \\
\text { Madagascar) }\end{array}$ & / & $\begin{array}{l}\text { Put } 1 \text { handful in water at } \\
\text { night } \\
2 \text { handfuls in } 1.5 \text { liter of } \\
\text { water. Boiling the }\end{array}$ & $\begin{array}{l}1 \text { teacup in the morning } \\
1 \text { teacup in the evening } \\
1 \text { teacup morning } \\
1 \text { teacup at midday } 1\end{array}$ & $\begin{array}{l}\text { C: Dang D. } \mathrm{N}^{\circ} 374 \\
\text { H: } 25583 / \mathrm{HNC} \\
\text { C: Leuwenberg A. J. } \\
\text { M. No } 9519\end{array}$ \\
\hline
\end{tabular}




\begin{tabular}{|c|c|c|c|c|c|c|c|}
\hline $\begin{array}{l}\text { Family of } \\
\text { plant }\end{array}$ & $\begin{array}{l}\text { Scientific } \\
\text { name }\end{array}$ & $\mathbf{n}$ & $\begin{array}{l}\begin{array}{l}\text { Vernacular name } \\
\text { (common name) }\end{array} \\
\end{array}$ & $\begin{array}{l}\text { Associated } \\
\text { plants }\end{array}$ & Preparation & $\begin{array}{l}\text { Posology for an adult } \\
\text { of } 70 \mathrm{~kg}\end{array}$ & Authentification \\
\hline \multirow{5}{*}{ Asteraceae } & Don. & & & & $\begin{array}{l}\text { mixture within a time } \\
\text { limit of } 15 \mathrm{~min}\end{array}$ & teacup in the evening & H: 43386/HNC \\
\hline & $\begin{array}{l}\text { Ageratum } \\
\text { conyzoides } \mathrm{L} \text {. }\end{array}$ & 2 & $\begin{array}{l}\text { Mejocktefeu } \\
\text { (King of grasses) }\end{array}$ & $\begin{array}{l}\text { Lemou } \\
\text { mecheu-cheu } \\
\text { (Lemon) }\end{array}$ & $\begin{array}{l}1 \text { handful in } 1 \text { liter of } \\
\text { water }\end{array}$ & $\begin{array}{l}1 \text { glass in the morning } \\
1 \text { glass in the evening. }\end{array}$ & $\begin{array}{l}\text { C: Leuwenberg A. J. } \\
\text { M. No } 7505 \\
\text { H: } 21155 / \text { SRF-CAM }\end{array}$ \\
\hline & $\begin{array}{l}\text { Bidens pilosa } \\
\text { L. }\end{array}$ & 1 & Kouamdou & / & $\begin{array}{l}\text { Boil } 1 \text { handful in } 1.5 \mathrm{~L} \\
\text { within a period of } 20 \\
\text { min }\end{array}$ & $\begin{array}{l}1 \text { glass in the morning. } \\
1 \text { glass in the evening }\end{array}$ & $\begin{array}{l}\text { C: Letouzey R. } \mathrm{N}^{\circ} \\
3417 \\
\text { H: } 4871 / \text { SRF-CAM }\end{array}$ \\
\hline & $\begin{array}{l}\text { Tridax } \\
\text { procumbens } \mathrm{L} .\end{array}$ & 1 & yère & / & $\begin{array}{l}1 \text { handful in } 2 \text { liters of } \\
\text { water }\end{array}$ & $\begin{array}{l}1 \text { glass in the morning } \\
1 \text { glass in the evening }\end{array}$ & $\begin{array}{l}\text { C: Swarbrick } N^{\circ} 276 \\
\text { H: } 33080 / H N C\end{array}$ \\
\hline & $\begin{array}{l}\text { vernonia } \\
\text { amygdalina } \\
\text { Delile }\end{array}$ & 2 & $\begin{array}{l}\text { Voup } \\
\text { (Dolé) }\end{array}$ & / & $\begin{array}{l}1 \text { handful to have } 1 \\
\text { glass of water }\end{array}$ & $\begin{array}{l}1 \text { glass in the morning } \\
1 \text { glass at midday } \\
1 \text { glass in the evening }\end{array}$ & $\begin{array}{l}\text { C: Letouzey R. } \mathrm{N}^{\circ} \\
14607 \\
\text { H: } 38383 / \mathrm{HNC}\end{array}$ \\
\hline Brassicaceae & $\begin{array}{l}\text { Brassica } \\
\text { oleracea } \mathrm{L} \text {. }\end{array}$ & 1 & (Cabbages) & / & Press to have 1 glass & $\begin{array}{l}1 \text { glass in the morning } \\
1 \text { glass at midday } \\
1 \text { glass in the evening. }\end{array}$ & $\begin{array}{l}\text { C: Westphal N } 9988 \\
\text { H: } 427418 / \mathrm{HNC}\end{array}$ \\
\hline $\begin{array}{l}\text { Caesalpiniacea } \\
\mathrm{e}\end{array}$ & $\begin{array}{l}\text { Senna } \\
\text { occidentalis (L) } \\
\text { Link }\end{array}$ & 1 & (Forgery kinkéliba) & / & $\begin{array}{l}\text { Boil } 1 \text { handful of root in } \\
1.5 \mathrm{~L} \text { of water within a } \\
\text { period of } 30 \mathrm{~min} \text {. }\end{array}$ & $\begin{array}{l}1 \text { glass in the morning } \\
1 \text { glass at midday } \\
1 \text { glass in the evening. }\end{array}$ & $\begin{array}{l}\text { C: Letouzey R. } \mathrm{N}^{\circ} \\
6476 \\
\text { H: } 7854 / \text { SRF-CAM }\end{array}$ \\
\hline Caricaceae & $\begin{array}{l}\text { Carica papaya } \\
\text { L. }\end{array}$ & 1 & $\begin{array}{l}\text { Dom pare } \\
\text { (Wild papaw tree) }\end{array}$ & / & $\begin{array}{l}\text { Boil } 2 \text { to } 3 \text { roots in } 1.5 \mathrm{~L} \\
\text { of water within a period } \\
\text { of } 15 \text { to } 20 \mathrm{~min} \text {. }\end{array}$ & $\begin{array}{l}1 \text { glass in the morning } \\
1 \text { glass at midday } \\
1 \text { glass in the evening. }\end{array}$ & $\begin{array}{l}\text { C: Betti J. L. N } 243 \\
\text { H: } 66 \text { 220/HNC }\end{array}$ \\
\hline Cucurbitaceae & $\begin{array}{l}\text { Citrullus } \\
\text { Lanatus } \\
\text { (Thumb.) } \\
\text { Matsum. \& } \\
\text { Nakai }\end{array}$ & 1 & $\begin{array}{l}\text { melon } \\
\text { (Watermelon) }\end{array}$ & / & $\begin{array}{l}\text { Soak a fruit in } 2 \mathrm{~L} \text { of } \\
\text { water or consume raw } \\
\text { seed }\end{array}$ & 1 & $\begin{array}{l}\text { C: Westphal No } 9249 \\
\text { H: } 42461 / H N C\end{array}$ \\
\hline Fabaceae & $\begin{array}{l}\text { Phaseolus } \\
\text { vulgarisL. }\end{array}$ & 1 & $\begin{array}{l}\text { Koun } \\
\text { (Bean) }\end{array}$ & I & $\begin{array}{l}1 \text { handful in } 2 \text { liters of } \\
\text { water }\end{array}$ & 3 teacups per day & $\begin{array}{l}\text { C: Westphal No } 8947 \\
\text { H: 42584/HNC }\end{array}$ \\
\hline Lamiaceae & $\begin{array}{l}\text { Ocimum } \\
\text { gratissimum } \mathrm{L} .\end{array}$ & 1 & (wild basil) & / & $\begin{array}{l}1 \text { handful of leaves in } \\
1.5 \mathrm{~L} \text { of water during } 30 \\
\text { minutes }\end{array}$ & $\begin{array}{l}1 \text { glass in the morning } \\
1 \text { glass at midday } \\
1 \text { glass in the evening }\end{array}$ & $\begin{array}{l}\text { C: Manning S. D. N }{ }^{\circ} \\
654 \\
\text { H: } 57748 / \mathrm{HNC}\end{array}$ \\
\hline Lauraceae & $\begin{array}{l}\text { Persea } \\
\text { americana } \\
\text { Mill. }\end{array}$ & 2 & $\begin{array}{l}\text { Chim Péya'a } \\
\text { (avocado tree) }\end{array}$ & / & $\begin{array}{l}\text { Slice } 2 \text { cores. Soak in } 1 \\
\text { liter of water then let } \\
\text { ferment for } 2 \text { days }\end{array}$ & $\begin{array}{l}1 \text { glass in the morning } \\
1 \text { glass in the evening }\end{array}$ & $\begin{array}{l}\text { C: Manning S. D. } \mathrm{N}^{\circ} \\
891 \\
\text { H: } 57756 / \mathrm{HNC}\end{array}$ \\
\hline Liliaceae & $\begin{array}{l}\text { Allium sativium } \\
\text { L. }\end{array}$ & 3 & $\begin{array}{l}\text { (Garlic of the } \\
\text { village) }\end{array}$ & I & $\begin{array}{l}\text { Slice } 1 \text { to } 2 \text { pods. Add } 1 \\
\text { liter of waterand boil the } \\
\text { mixture during } 5 \\
\text { minutes }\end{array}$ & $\begin{array}{l}3 \text { teacups per day within } \\
\text { a period of } 9 \text { months. }\end{array}$ & $\begin{array}{l}\text { C: Westphal No } 10019 \\
\text { H: } 44810 / H N C\end{array}$ \\
\hline Mimosaceae & $\begin{array}{l}\text { Tetrapleura } \\
\text { tetraptera } \\
\text { (Schum. et } \\
\text { Thom.) Taub. }\end{array}$ & 1 & (4 sides) & / & $\begin{array}{l}\text { Clean and soak } 1 \text { fruit in } \\
1.5 \mathrm{~L} \text { of water }\end{array}$ & $\begin{array}{l}1 \text { glass in the morning } \\
1 \text { glass at midday } \\
1 \text { glass in the evening. }\end{array}$ & $\begin{array}{l}\text { C: Sonke B. } \mathrm{N}^{\circ} 481 \\
\text { H: } 65877 / \mathrm{HNC}\end{array}$ \\
\hline Moringaceae & $\begin{array}{l}\text { Moringa } \\
\text { oleifera } \mathrm{L} \text {. }\end{array}$ & 1 & (Moringa) & / & $\begin{array}{l}1 \text { coffee spoon of leaves } \\
\text { in } 1 \text { glass of water or } 3 \\
\text { grains each morning and } \\
\text { evening }\end{array}$ & $\begin{array}{l}1 \text { glass in the morning } \\
\text { before eating } \\
1 \text { glass in the evening } \\
\text { after the meal }\end{array}$ & $\begin{array}{l}\text { C: Leuwenberg A. J. } \\
\text { M. No } 9497 \\
\text { H: } 49178 / \mathrm{HNC}\end{array}$ \\
\hline & $\begin{array}{l}\text { Eucalyptus } \\
\text { globulus Labill. }\end{array}$ & 2 & $\begin{array}{l}\text { Chim booner } \\
\text { (Eucalyptus) }\end{array}$ & / & $\begin{array}{l}\text { Boil } 1 \text { handful in } 1 \text { liter } \\
\text { of water }\end{array}$ & $\begin{array}{l}1 \text { glass in the morning } \\
1 \text { glass in the evening. }\end{array}$ & $\begin{array}{l}\text { C: Letouzey R. sn } \\
\text { H: 477/SRFCM }\end{array}$ \\
\hline Myrtaceae & $\begin{array}{l}\text { Psidium } \\
\text { guajava } \mathrm{L} .\end{array}$ & 1 & $\begin{array}{l}\text { Chim kouopeu } \\
\text { (Guava tree) }\end{array}$ & / & $\begin{array}{l}\text { Boil } 1 \text { handful of leaves } \\
\text { in water to obtain } 1 \text { liter } \\
\text { of medicine }\end{array}$ & $\begin{array}{l}1 \text { goblet in the morning } \\
1 \text { goblet at midday } \\
1 \text { goblet in the evening }\end{array}$ & $\begin{array}{l}\text { C: Mbamba No } 1010 \\
\text { H: } 65619 / \mathrm{HNC}\end{array}$ \\
\hline Poaceae & Zea mays $\mathrm{L}$. & 1 & $\begin{array}{l}\text { Gbom } \\
\text { (corn) }\end{array}$ & I & $\begin{array}{l}1 \text { handful in } 1 \text { glass of } \\
\text { water or } 1 \text { spoon of } \\
\text { powder in } 1 \text { glass of } \\
\text { water }\end{array}$ & $\begin{array}{l}3 \text { to } 4 \text { teacups per day } \\
\text { before eating }\end{array}$ & $\begin{array}{l}\text { C: Dang D. No } 81 \\
\text { H: } 18625 / \text { SRF-CAM }\end{array}$ \\
\hline Rosaceae & $\begin{array}{l}\text { Rubus } \\
\text { rigidus } \mathrm{Sm} . \\
\text { Var. } \\
\text { camerounensis } \\
\text { R. Let. }\end{array}$ & 1 & (wild mulberry tree) & / & $\begin{array}{l}\text { Boil } 1 \text { handful of leaves } \\
\text { in water to obtain } 1 \text { liter } \\
\text { of medicine }\end{array}$ & $\begin{array}{l}1 \text { glass in the morning } \\
1 \text { glass at midday } \\
1 \text { glass in the evening. }\end{array}$ & $\begin{array}{l}\text { C:Jacques Félix-H } N^{\circ} \\
8457 \\
\text { H: } 25649 / \mathrm{HNC}\end{array}$ \\
\hline Rubiaceae & $\begin{array}{l}\text { Nauclea } \\
\text { latifolia } \mathrm{Sm} .\end{array}$ & 1 & Nguèn & I & $\begin{array}{l}\text { Boil } 3 \text { to } 4 \text { pieces in } 2 \\
\text { liters of water. Add } 3 \text { to } \\
4 \text { pieces of corossolier }\end{array}$ & $\begin{array}{l}1 / 2 \text { glass in the morning } \\
1 / 2 \text { glass at midday } \\
1 / 2 \text { glass in the evening } \\
\text { for child. } \\
1 \text { glass in the morning }\end{array}$ & $\begin{array}{l}\text { C: Biholong M. N }{ }^{\circ} 438 \\
\text { H: } 42156 / \mathrm{HNC}\end{array}$ \\
\hline
\end{tabular}




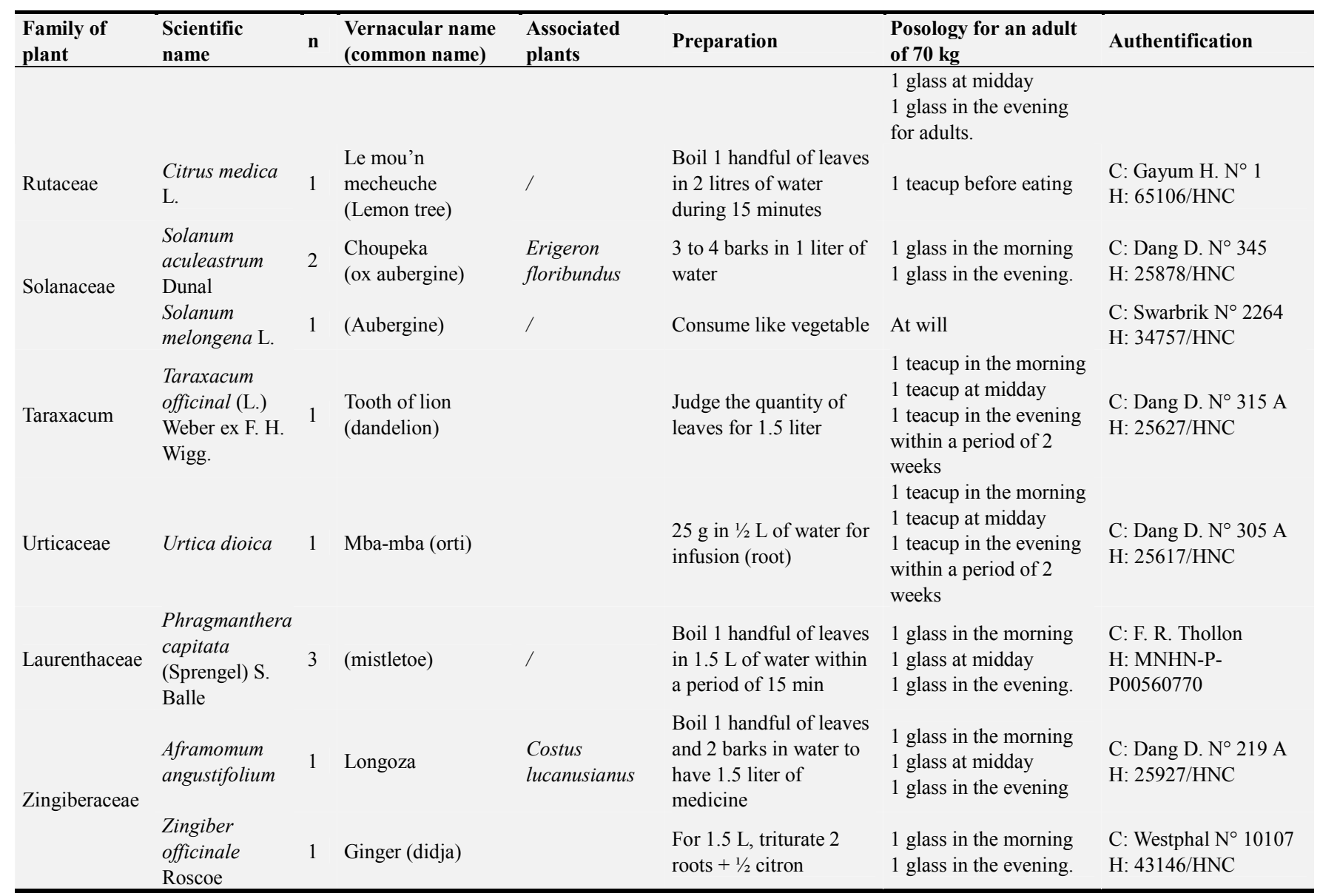

C: identification of collector; $n$ : frequency of appearance of the plant for ethnopharmacological use, H: record number from the herbarium.

\subsubsection{Frequency of the Parts Used}

Figure 1 presents the frequencies of the various parts of the plants used for the various preparations in the study zone. This reveals that the leaves constitute the most used part with an approximate percentage of $45 \%$; followed by the fruits $(15 \%)$, the roots $(11 \%)$ and the barks $(9 \%)$. Seven percent $(7 \%)$ of the healers use the whole plant instead of being interested only in one part.

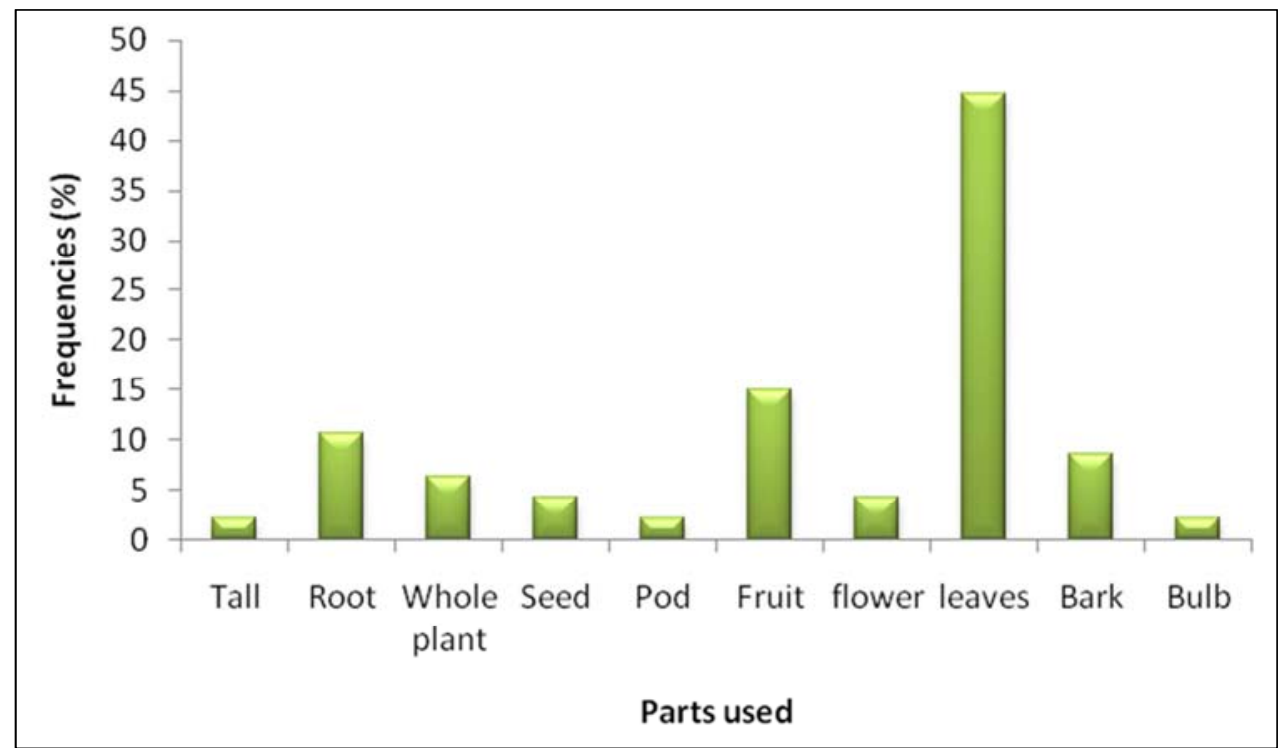

Figure 1. The frequencies of the different parts of the plants used by the traditional healers to prepare the antidiabetic drug. 


\subsubsection{Mode of Preparation of the Plants by the Healers}

The frequencies of the various modes of preparation are presented by the diagram of Figure 2. It appears that the most used mode of preparation by the healers is decoction $(51.28 \%)$ followed by maceration $(28.21 \%)$.

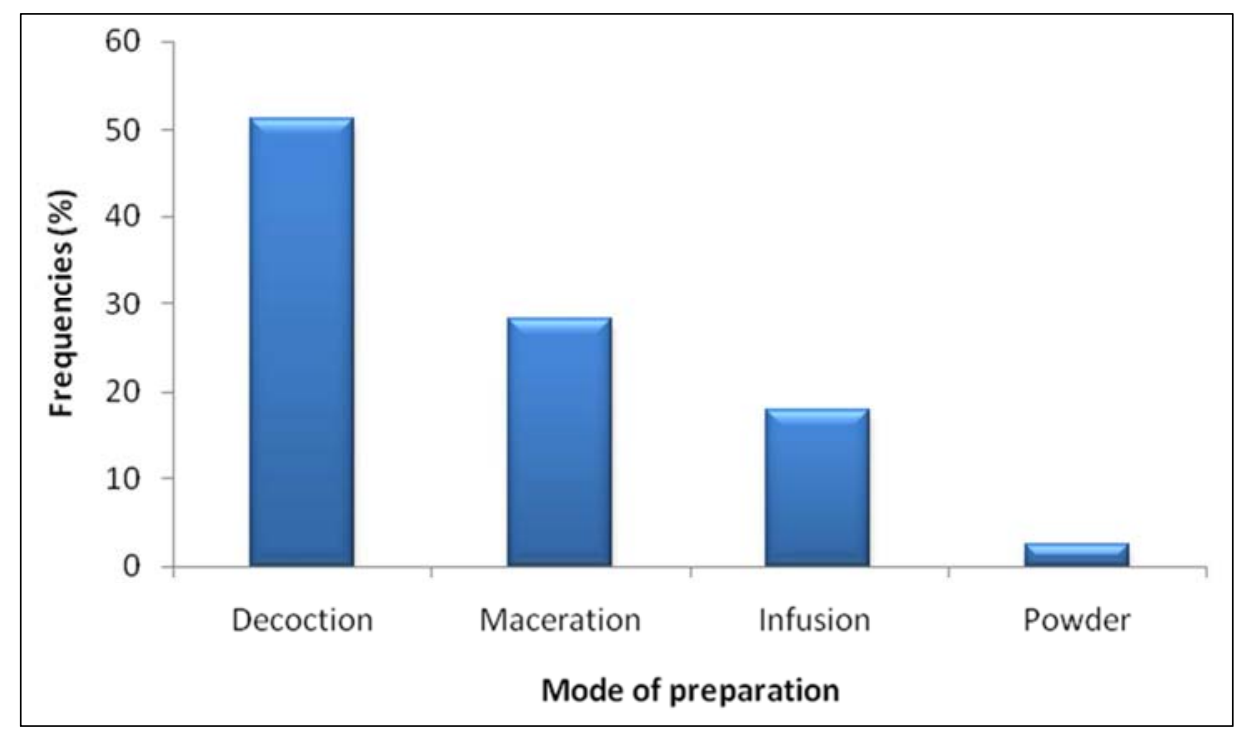

Figure 2. Frequency of the various modes of preparation of the antidiabetic drug.

\subsection{Antidiabetic Properties of Phragmanthera Capitata}

\subsubsection{Effect of the Extract in the Normal Glycaemia Rats}

Figure 3 below summarizes the effects of various doses of the extract of Phragmanthera capitata on the glycaemia of normal rats. This reveals that in treated animals in general and with the extract of Phragmanthera capitata particularly, the glycaemia of the rats drops gradually and significantly over time. The hypoglycaemiant effect of the glibenclamide is very significant between $1 \mathrm{~h} 00$ and $2 \mathrm{~h} 00$.

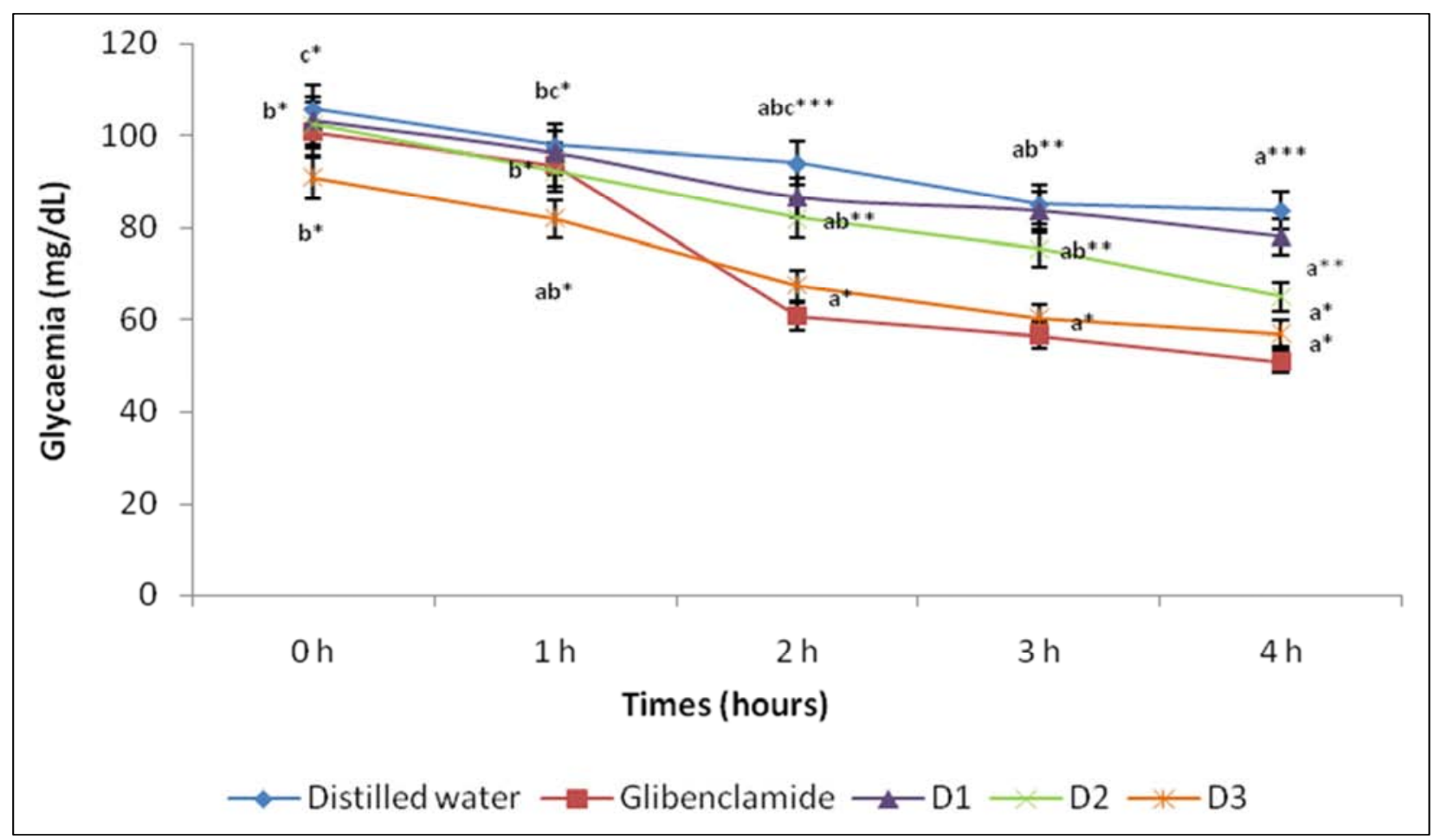

Figure 3. Evolution of glycaemia during 4 hours following the administration by oral way of three doses of P. capitata extract.

The values of the glycaemia related to the same curve and affected by same letter, just as those related to the same column and affected by same number of stars are not statistically significant with the threshold of $5 \% . \mathrm{N}=5$ repetitions. 


\subsubsection{Effect of the Extract in Temporary Hyperglycaemic Rats}

Figure 4 below presents the effects of various doses of the extract of Phragmanthera capitata on temporary hyperglycaemia caused by oral overload of glucose $(4 \mathrm{~g} / \mathrm{kg})$ in the pretreated rats. Thirty minutes after administration of glucose, hyperglycaemia whose level is variable according to the substances and doses with which animals are pretreated was observed. This level is more important in the negative control rats (distilled water), thus showing an antihyperglycemic effect of the aqueous extract of Phragmanthera capitata. This hyperglycemia is stabilized between 30 and $60 \mathrm{~min}$, then falls in the animals pretreated with the plant extract as a function of doses. The effect of D3 dose is almost similar to that of glibenclamide (reference drug).

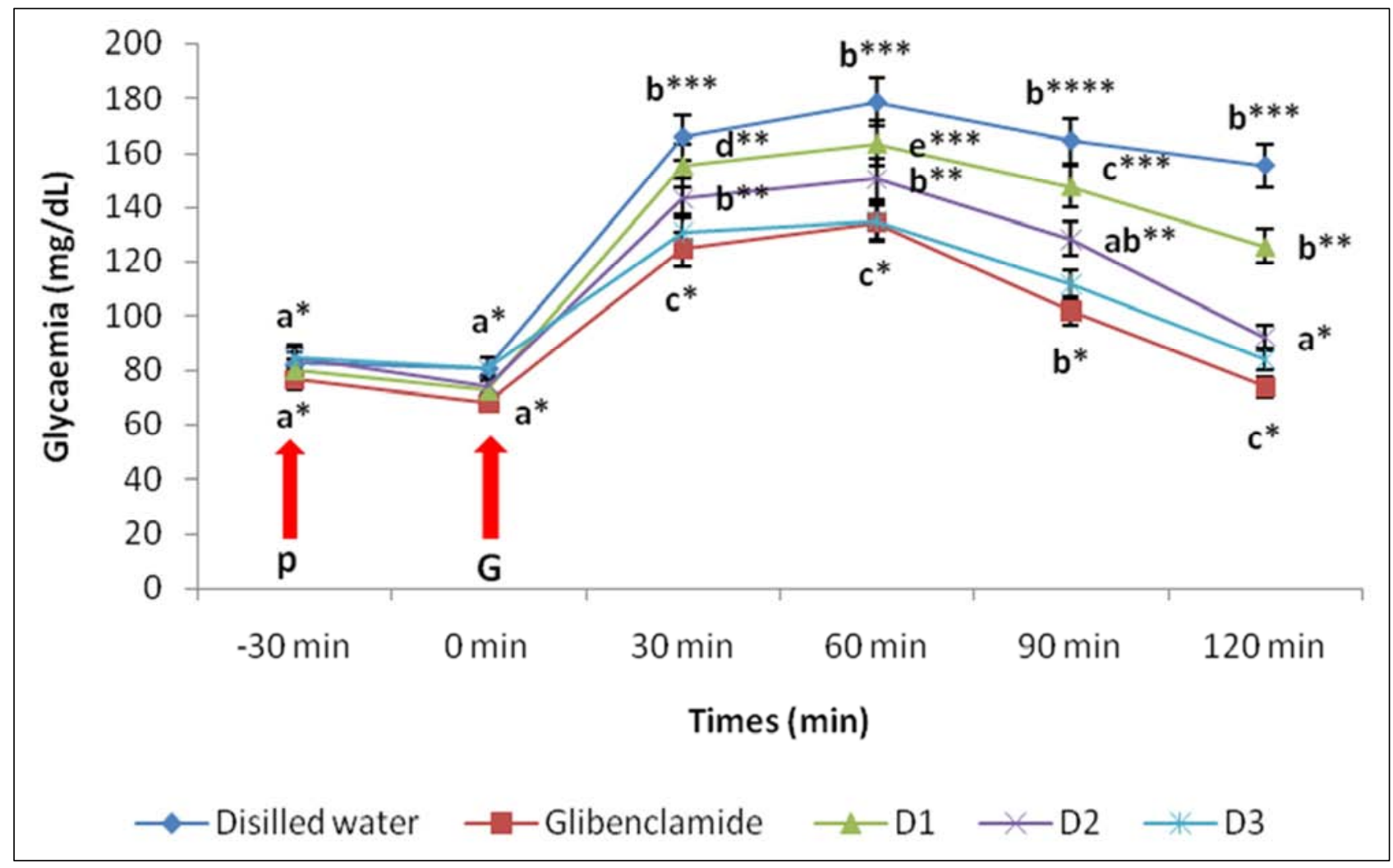

Figure 4. Variation of glycaemia in the temporary hyperglycaemia rats treated with three doses of P. capitata extract.

The values of glycaemia related to the same curve and affected by same letter, just as those related to the same column and affected by same number of stars are not statistically significant with the threshold of 5\%. N=5 repetitions. P: administration of Product, G: administration of glucose.

\subsubsection{Effect of the Extract on the Hyperglycaemia of the Diabetic Rats}

The effect of Phragmanthera capitata extract on glycaemia of diabetic rats is presented in Figure 5. Glycaemia of neutral and negative control rats remains constant in the course of time of experimentation. The effect of D1 dose is low since glycaemia of rats treated at this dose remained very high until the end of experiment. On the other hand, D2 and D3 doses caused a significant and progressive fall of glycaemia of rats during the first week. The effect of D3 dose was comparable to that of glibenclamide at the tested dose. On the evening of the 7 th day, animals were not treated and their glycaemia increased significantly in rats treated with glibenclamide and in a non significant way in rats treated with the D3 dose. Glycaemia then reduces with the resumption of treatment on the 8th day. 


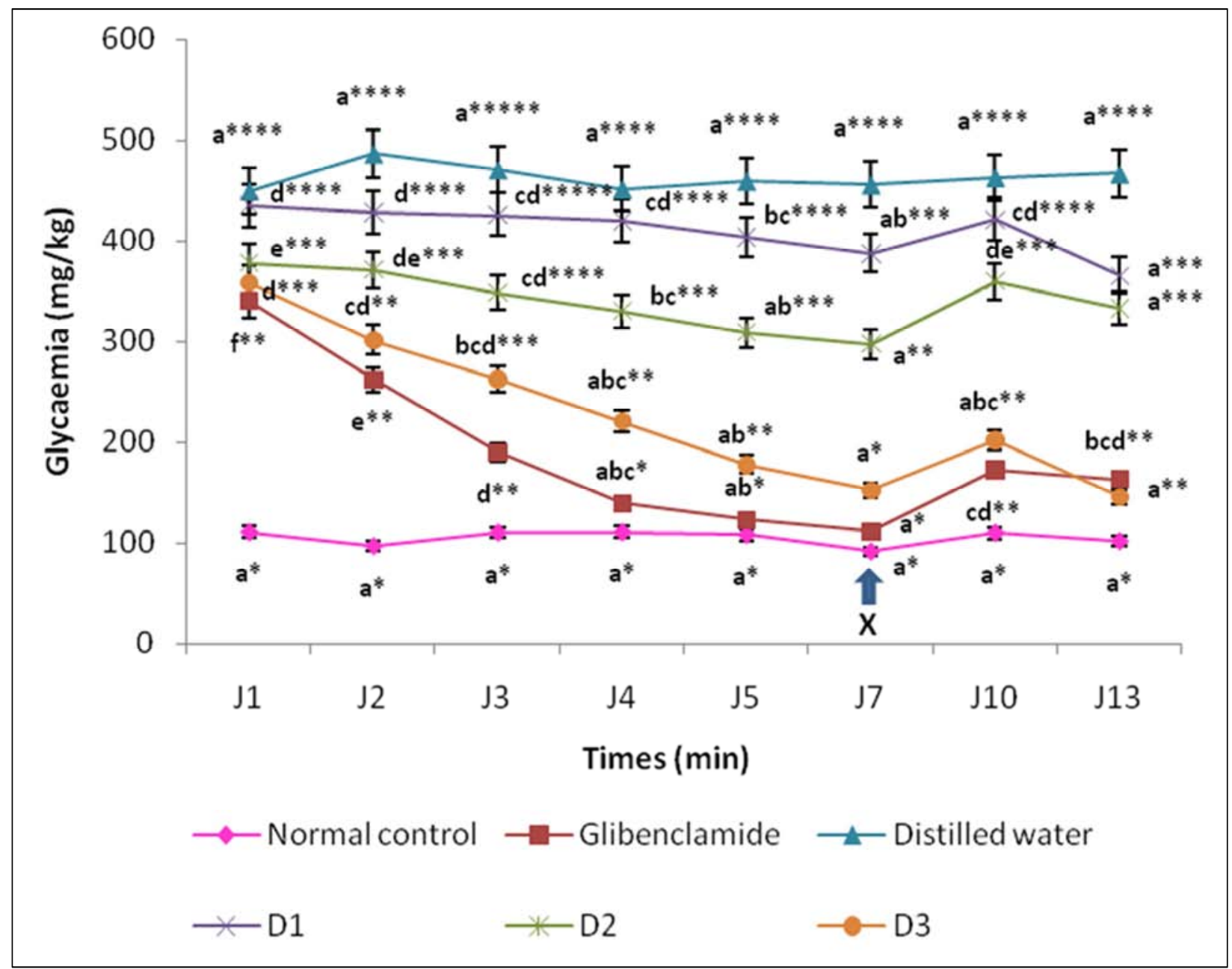

Figure 5. Evolution of glycaemia ofdiabetic rats during two weeks following daily administration of P. capitata extract.

The values of glycaemia related to the same curve and affected by same letter, just as those related to the same column and affected by same number of stars are not statistically significant with the threshold of $5 \% . \mathrm{N}=5$ repetitions. $\mathrm{J}=$ days, $\mathrm{X}=$ stop of the treatment the evening and recovery the 8 th day.

\section{i. Effect of Phragmanthera Capitata Extract on the Hematological Parameters}

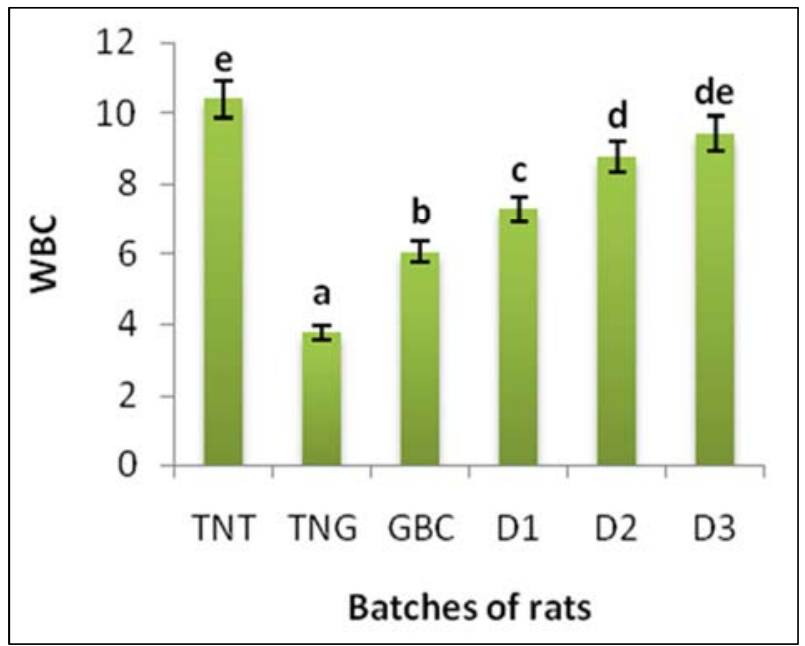

(a)

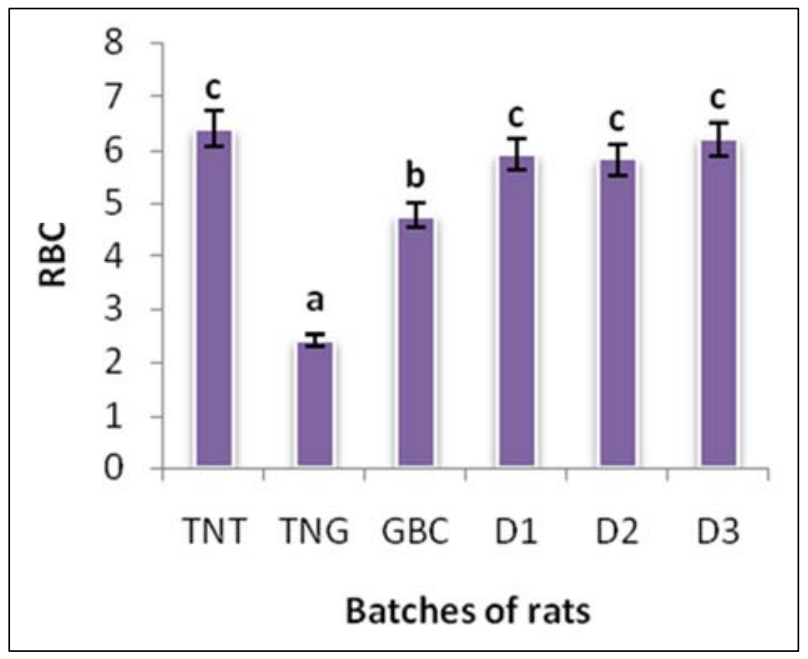

(b) 


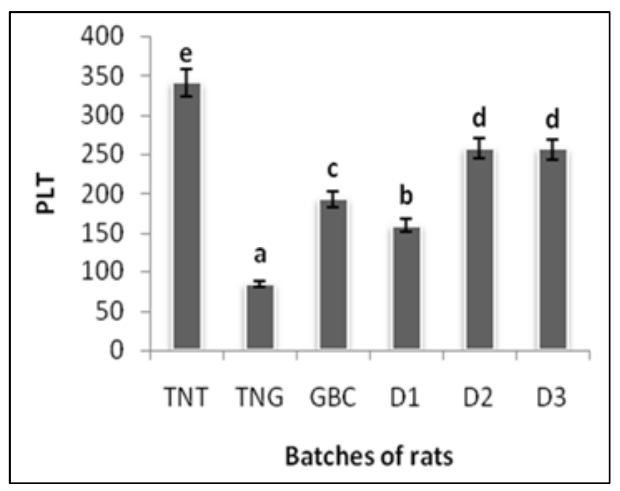

(c)

Figure 6. Hematologic parameters of the batches of studied rats.

(A): rate of white blood cell (WBC) $\left(10^{3} / \mu \mathrm{L}\right),(\mathrm{b})$ : rate of red blood cell (RBC) $\left(10^{6} / \mu \mathrm{L}\right),(\mathrm{c})$ : rate of platelets (PLT) $\left(10^{3} / \mu \mathrm{L}\right)$. TNT: normal control, TNG: negative control (distilled water), GBC: glibenclamide

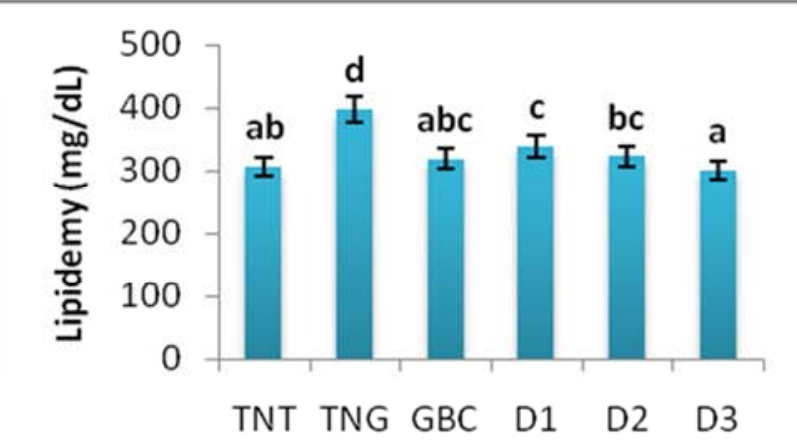

Batches of rats

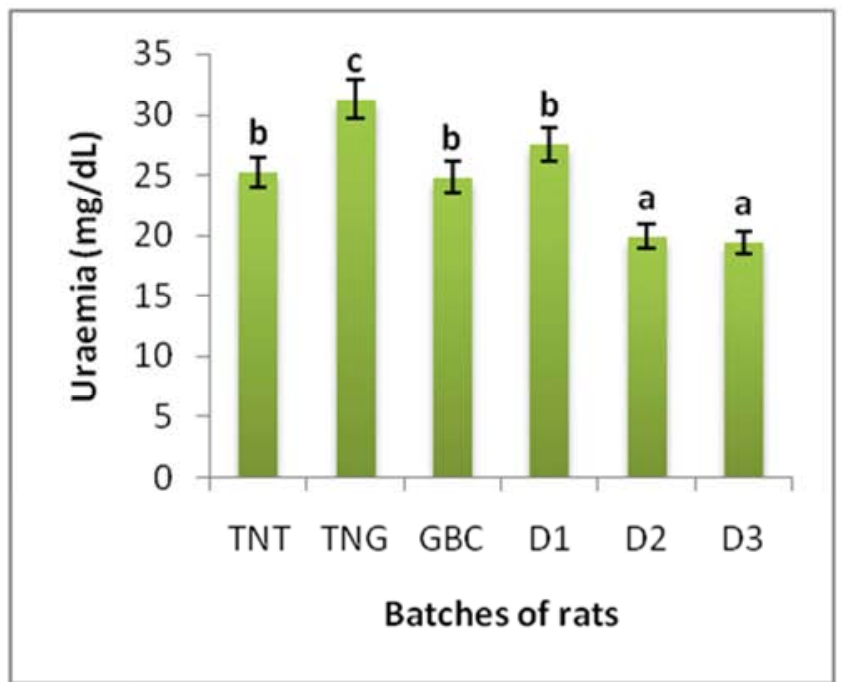

The values of white blood cells, erythrocytes and platelets of various batches of diabetic rats are presented in Figure 6 below. This reveals that the diabetic state induced a leucopenia (significant fall of the rate of $\mathrm{WBC}$ ), an anaemia (significant fall of the rate of RBC) and a thrombopenia (significant fall of the rate of PLT) of the negative control rats and would be the sign of hematopoïesis disturbance in these rats. The administration of the extract to the rats corrected these anomalities, depending on the doses.

\section{ii. Effect of Phragmanthera Capitata Extract on the Serum Biochemical Parameters}

For all the batches of the studied diabetic rats, the results of various types of serum biochemical parameters are presented in Figure 7.
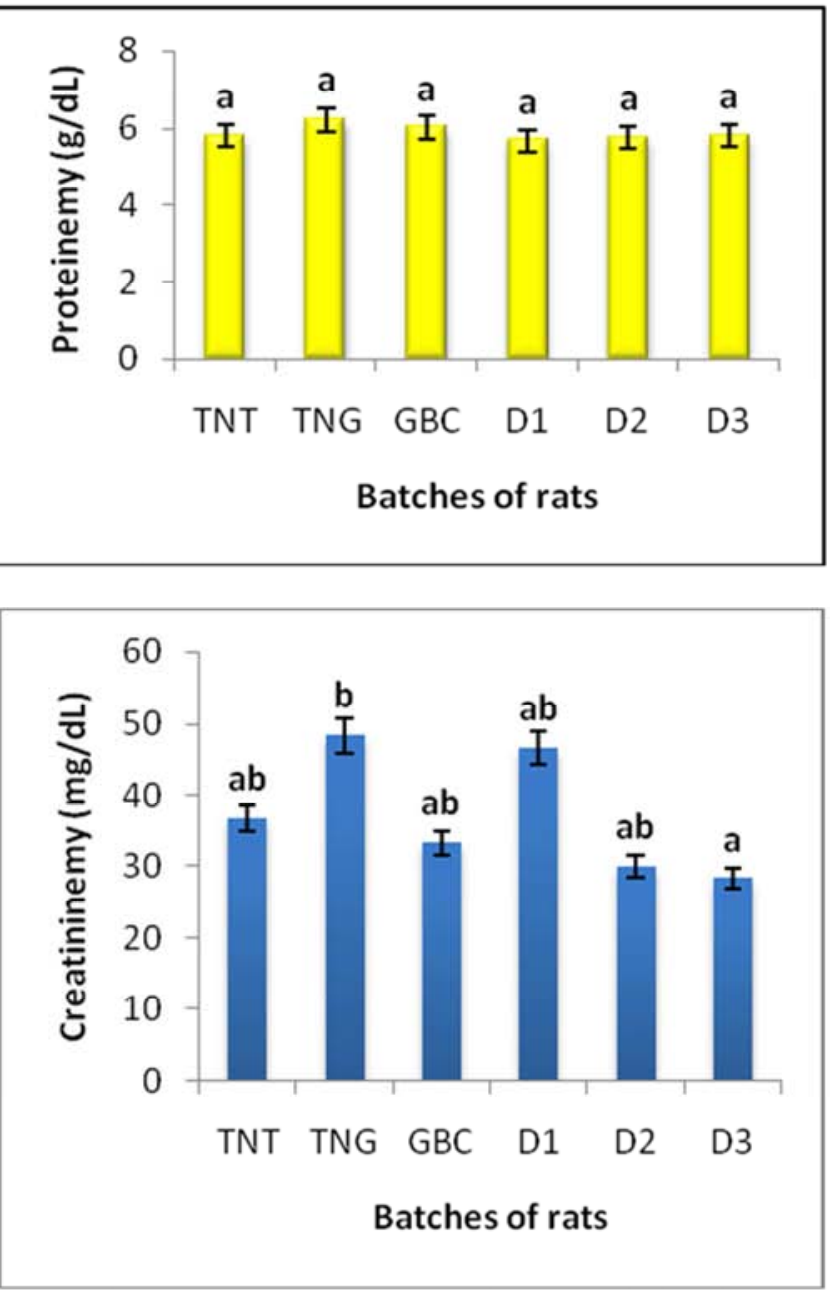

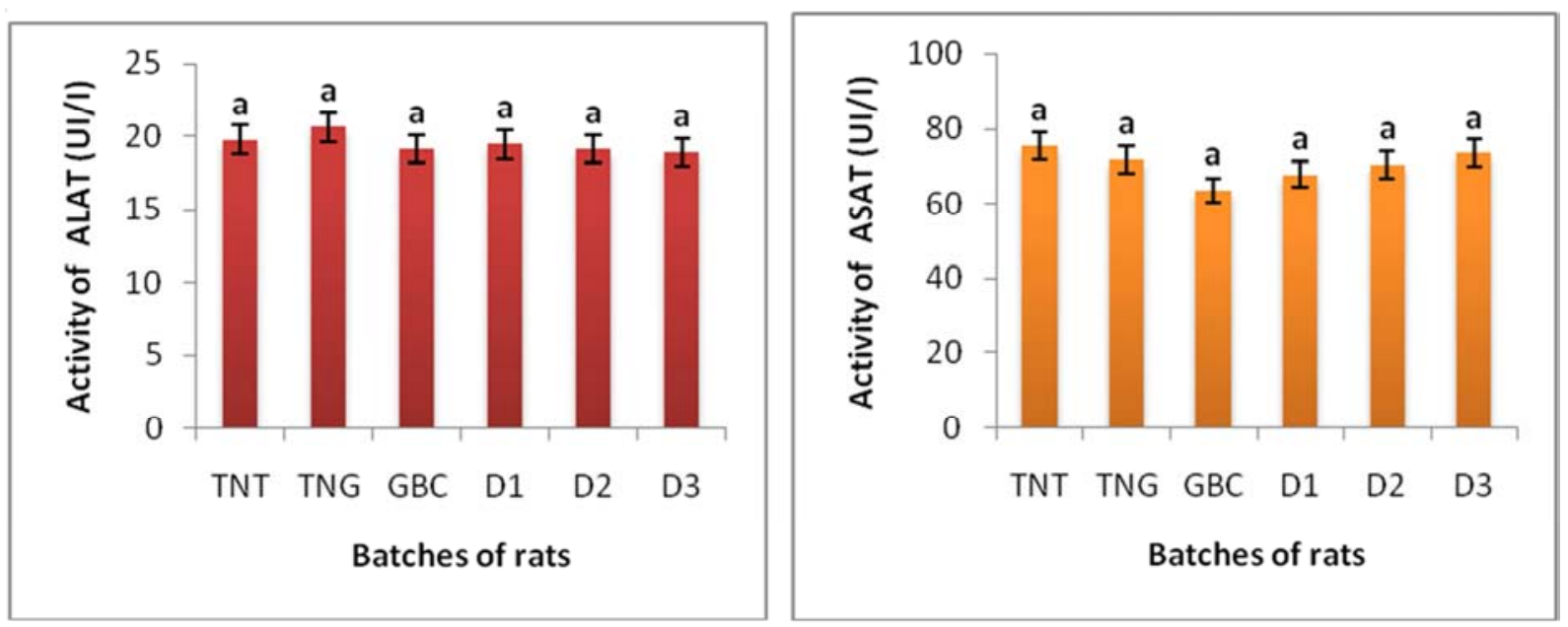

Figure 7. Biochemical parameters of the various batches of studied rats.

TNT: normal control, TNG: negative control (distilled water), GBC: glibenclamide, ASAT: Glutamate Oxolo-acetate transaminase and ALAT: Glutamate Pyruvate transaminase.

The results revealed a high rate of lipidemia and uraemia. The administration of Phragmanthera capitata extract caused a significant reduction of these parameters. Furthermore, proteinemia, creatininemia as well as the activity of transaminases ALAT and ASAT were comparable in all the batches of diabetic rats.

\subsection{Phytochemical Composition of Phragmanthera Capitata Extract}

Table 3 summarize the classes of compounds found in Phragmanthera capitata extract. The extract of the leaves of plant contains tannins, flavonoïdes, saponins, steroids and terpenes.

Table 3. Phytochemical composition of P. capitata extract.

\begin{tabular}{ll}
\hline Class of compounds & Results \\
\hline Tanins & + \\
Flavonoides & + \\
Alkaloids & - \\
Saponines & + \\
Steroides & + \\
Terpenes & + \\
\hline
\end{tabular}

+: Presence; -: Absence

\section{Discussion}

On the whole, 35 species of plants were listed by 27 traditional healers, male being in majority. This male prevalence is explained by the fact that virtues of plants are ancestral knowledge which is generally transmitted from generation to generation mainly to the successor generally of the male gender [19]. Moreover, it is largely admitted that knowledge of medicinal herbs is a reserved domain of men in Africa [20]. Healers showed a good knowledge of the disease and have means to diagnose it. They admitted that the disease can be hereditary or result from a misuse of sugar by the body, the overweight, as well as the bad feeding habits being risk factors.

The family of Asteraceae was strongly represented $(14.81 \%)$ at the end of the investigation. This strong predominance of Asteraceae is explained by the fact that this family is one of the most represented plant families on earth $[21,22]$. This representativeness was also observed following ethnopharmacological investigations on antidiabetic plants in Ivory Coast, Algeria, Benin and Morocco by [22-25] respectively.

Several species of plants are regularly used in preparation of phytomedicationss: Allium sativium, Aloe barbadensis, Phragmanthera capitata, Allium cepa, Mangifera indica, Catharenthus roseus, Vernonia amygdalina, Persea americana et Eucalyptus globulus. A strong frequency of quotation of a plant during an ethnobotanical investigation is a good indicator of its effectiveness. One can thus think that, among these nine plants, the most represented could be effective in the treatment of diabetes mellitus [26].

The preparation of traditional drug is done primarily by decoction. The leaves are part mainly used in these preparations whose administration route is oral. The preponderance of decoction would be due to the fact that compared to infusion; it softens the hard parts of plants to allow a more complete extraction of active ingredients [27]. It is preserved longer than maceration which rather ferments quickly [27]. The prevalence of leaves would be explained by the fact that they are very abundant, generally available throughout the year, of easy accesses and collection as well as easy handling [22]. In addition, proper collection of leaves preserves plant from destruction [26, 28]. The oral administration of preparations would be explained by the fact that traditional healers know that the source of the disease is from the interior of the body $[22,25]$.

The administration of Phragmanthera capitata extract causes a significant fall of basic glycaemia of the normoglycemic, temporary hyperglycemic and diabetic rats. This extract contains saponins, flavonoides, tannins, steroids 
and terpenes. It is clearly established that saponins [29] terpenes [30] and tannins [31] have antidiabetic properties. Some flavonoides like quercetins have the capacity of increasing secretion of insulin by pancreatic $\beta$ cells [32]. Other flavonoides inhibit glucose carriers in the intestine or decrease expression of the genes which control neoglucogenesis and then reduce the degradation of glycogen [33-36]. Tannins would act at the cellular level by supporting the action of insulin [37]. One can thus think that compounds belonging to these various groups act individually or in synergy. The administration of $P$. capitata extract during 14 days in diabetic rats brought back glycaemia practically to the normal value on the 13th day of treatment. It is consequently possible that this extract inhibits the activity of digestive enzymes such as $\alpha$-glucosidase or amylases. This inhibition thus reduces intestinal absorption of glucose coming from digestion of polysaccharides [38]. Lectines and viscotoxines present in Viscum album, the Europeen misteletoe, are able to inhibit the activity of $\alpha$-glucosidase [39]. Phragmanthera capitata, an African species of mistletoe, could contain the same type of substances. So, the extract could act by stimulating secretion of insulin by residual $\beta$ cells or by potentiating the effects of insulin or by miming the effects of insulin. Indeed, the capacity of lectines to stimulate the release of insulin by isolated cells has been described previously [40]. The effect of the extract at D2 and D3 doses is comparable to that of glibenclamide (insulinosecretor hypoglycaemiant sulphamide). This latter binds to a specific receptor on the membrane of pancreatic $\beta$ cells in the vicinity of potassic channel ATP depending and causes its closing. This involves a membrane depolarization of $\beta$ cells with opening of the calcic channels voltage dependant and an impulse on $\mathrm{Ca}^{2}+$ thus starting by exocytose of the granules of insulin secretion [41]. It would be difficult to specify the mode of action of $P$. capitata because the extract is made up of a mixture of compounds which can interfer or have synergistic action.

Leucopenia, anaemia and thrombopenia were observed in the untreated diabetic rats and would be the sign of a disturbance of hematopoïesis in these rats. The administration of the extract to rats corrected these abnomalities according to the administered doses better than the reference drug (glibenclamide). The previously studies showed that spathulenol, a sesquiterpene has an immunomodulator effects [42]. Terpenes, flavonoïdes and tannins contained in the extract would have reduced the hyperglycaemia of diabetic rats by activating the hematopoïesis. In addition, the administration of $P$. capitata extract produced a significant reduction in serum lipidemy, an important risk factor of diabetes. This hypolipidemiant effect can also be the consequence of hypoglycaemiant effect of the extract. Beside, a study showed the hypolipidemiant effect of flavonoides, terpenes and phenolic compounds [36]. One can thus think that, by reducing glycaemia, flavonoides and terpenes contained in the extract reduced at the same time serum rate of lipids, by stimulating lipogenesis from glucose transported in the cells and by inhibiting lipolysis
[43]. A significant increase of urea concentration was noted in untreated diabetic rats sign of a renal dysfunction in these rats, resulting from toxicity of alloxan [44, 45]. Administration of the extract caused a significant reduction in uraemia thus showing a protective effect on kidney. The determination of the activity of transaminases ALAT and ASAT revealed a comparable activity in all the batches of studied rats showing that there was no hepatic toxicity due to alloxan or plant extract administration. The beneficial effect of the extract on kidneys and liver would be ascribed to its capacity to reduce glycaemia and oxidative stress induced by alloxan and/or hyperglycaemia. Indeed, the studies of [46] show that polyphenols and triterpenes found in the extract have the ability to neutralize free radicals resulting from oxidation of alloxan or formed during diabetes state.

\section{Conclusion}

The administration of Phagmanthera capitata extract to diabetic rats significantly decreased hyperglycaemia. The dose and the double dose of the extract used by traditional healers were effective against diabetes. These results thus justify the traditional use of this plant in the treatment of diabetes mellitus. But at this stage, the exact mechanism of action of the extract is not known. This will constitute one of our objectives in the next study.

\section{Ethics Approval and Consent to Participate}

All studies involving animals were conducted according to the ethical guidelines of the Committee for Control and Supervision of Experiments on Animals (Registration no. 173/CPCSEA, dated 28 January, 2000), Government of India, on the use of animals for scientific research.

\section{Consent to Publish}

Not applicable

\section{Availability of Data and Materials}

Not applicable

\section{Competing Interests}

The authors have no conflict of interest to declare.

\section{Funding}

This study was supported in part by the University of Dschang and the Cameroonian Ministry of Higher Education.

\section{Authors' Contributions}

$\mathrm{CF}$ is the field investigator and has drafted the manuscript. 
J-RK designed the study and GSSN supervised field work. All authors read and approved the final manuscript.

\section{Acknowledgements}

The authors express their gratitude to traditional healers of the district of Foumban for their frank collaboration, as well as the regional hospital of Bafoussam where the main part of the analyses was done.

\section{References}

[1] FID. Atlas du diabète de la FID. 6 édition, 2014.

[2] Tsabang N, Guedje NM, Nnanga J, Tamzé V, Biyiti L, Agbor T, Agbor G, Donfangsiteli N, Kinga J, Essamé OJL. Production des médicaments traditionnels améliorés au Cameroun: cas d'un hypoglycémiant oral. Health sciences and disease. 2012; 12:1-9.

[3] Mbanya NJC, Motala AA, Sobngwi E, Assah KF, Enoru TS Diabetes in sub-SaharanAfrica. Seminar. 2010; 375:2254-6.

[4] Colagiuri S, Colagiuri R, Na'ati S, Muimuiheata S, Hussain Z, Palu T, The prevalence of diabetes in the Kingdom of Tonga. Diab. Care. 2002; 25:1378-83.

[5] Mannan A, Rupa AB, Azam KN, Nasir Ahmed N, Hasan N. A Quick Review on Anti-diabetic Plants and Action of Phytochemicals. Intern. J. Ad. Res. 2014; 2:227-9.

[6] Sy GY, Barbosa FS, Wele A, Gueye PM, Gueye CD, Cisse A, Dieye AM, Bassene E, Faye B. Activité antihyperglycemiante de la fraction F2 de l'extrait total acétonique de feuilles de vernonia colorata (composeae). Pharm. Méd. Trad. Africaines. 2008; 15:6-10.

[7] Chabane D, Saidi F, Rouibi A, Azine K. Activité hypoglycémique de l'extrait aqueux d'AjugaivaL. schreber chez les rats diabétiques induite par l'alloxane. Afrique Science. 2013; 9:120-7.

[8] Gning SB, Thiam M, Fall F, et al. Le diabète sucré en Afrique subsaharienne: aspects épidémiologiques, difficultés de prise en charge. Med. Trop. 2007; 67:607-11.

[9] Okigbo RN, Nmeka IN. Control of Yam tuber rot with leaf Extracts of Xylopiaaethiopica and Zingiberoffinale. African J. Biotechnol. 2005; 4:804-7.

[10] Okigbo RN, Omodamiro OD. Antimicrobial effect of leaf extract of pigeon pea (Cajanuscajan (L) Mill sp) on some human pathogen. J. Herbs, spices Med. Plants. 2006; 12:11727.

[11] Fleurentin, J. L'ethnopharmacologie au service de la thérapeutique: sources et méthodes. Hegel. 2012; 2:12-8.

[12] WHO. Stratégie de l'OMS pour la médecine traditionnelle pour 2014-2023. Genève; 2013.

[13] Noumi E, Yumdinguetmun R. Plants and treatment of prostatic diseases in Foumban (West Region, Cameroon). Syllabus Review. 2010; 2:9-16.

[14] Trotter RT, Logan MH. Informant consensus: a new approach for identifying potentially effective medicinal plants. In:
Etkin, N. L. (Ed.), Plants in Indigenous Medicine and Diet, Behavioural Approaches. Redgrave Publishing Company. Bredford Hills. New York: 1986. p. 91-112.

[15] Telefo PB. Contribution à l'étude des plantes médicinales du Cameroun: Influence de l'extrait aqueux du mélange des feuilles d'Aloe buettneri A. Berger (Liliacées), Dicliptera verticillata GJH Amshoff (Acanthacees), Hibiscus macranthusHochst ex Arich (Malvacees), Justicia insularis T. Anders (Acanthacées), sur certains paramètres biochimiques et physiologiques de la reproduction chez la rate. Thèse de Doctorat $3^{\mathrm{e}}$ cycle en Biochimie. Université de Yaoundé I, Cameroun; 1998.

[16] Szkudelski T. The Mechanism of Alloxan and Streptozotocin Action in B Cells of the Rat Pancreas. Physiol. Res. 2001; 50:536-46.

[17] Ndomou M, Djidjou KP, Ayong NM, Gouado I, Tchiegang C. Evaluation de l'activité antidiabétique des extraits de feuilles de Gnetum africanum et Gnetum bulchozzianum (Gnétacées). Sciences, Technologies et Développement. 2014; 15:60-5.

[18] Bruneton J. Pharmacognosie, Phytochimie, Plantes médicinales. $3^{\text {ème }}$ Edition. Lavoisier. Paris; 1999.

[19] Klotoé JR, Dougnon TV, Koudouvo K, Atègbo JM, Loko F, Akoègninou A, Aklikokou K, Dramane K, Gbeassor M. Ethnopharmacological survey on antihemorrhagic medicinal plants in South of Benin. Eur. J. Med. Plants. 2013; 3:40-51.

[20] Cheikhyoussef A, Shapi M, Matengu K, Ashekele HM. Ethnobatanical study of indigenous knowledge on medicinal plant use by traditional healers in Oshikoto region, Namibia. J. Ethnobiol. Ethnomed. 2011; 7:1-11.

[21] Marles RJ, Farnsworth NR. Antidiabetic plants and their active constituents. Phytomedicine. 1995; 2:137-89.

[22] Tra-BI FH, Irié GM, N'gaman KCC, Mohou CHB. Études de quelques plantes thérapeutiques utilisées dans le traitement de l'hypertension artérielle et du diabète: deux maladies émergentes en Côte d'Ivoire. Sciences \& Nature. 2008:5:39-48.

[23] Azzi R, Djaziri R, Lahfa F, Sekkal FZ, Benmehdi H, Belkacem N. Ethnopharmacological survey of medicinal plants used in the traditional treatment of diabetes mellitus in the North Western and South Western Algeria. Journal of Med. Plants Res. 2012; 6:2041-50.

[24] Fah L, Klotoé JR, Dougnon V, Koudokpon H, Fanou VBA, Dandjesso C, Loko F. Étude ethnobotanique des plantes utilisées dans le traitement du diabète chez les femmes enceintes à Cotonou et Abomey-Calavi (Bénin). J. Anim. Plant Sci. 2013; 18:2647-58.

[25] Orch H, Douira A, Zidane L. Étude ethnobotanique des plantes médicinales utilisées dans le traitement du diabète, et des maladies cardiaques dans la région d'Izarène (Nord du Maroc). J. Applied Biosci. 2015; 86:7940-56.

[26] Kone D. Enquête ethnobotanique de six plantes médicinales maliennes - extraction, identification d'alcaloïdes caractérisation, quantification de polyphénols: étude de leur activité antioxydante. Thèse de Doctorat en Chimie Organique. Université de Bamako, Mali; 2009.

[27] Azwanida NN. A Review on the Extraction Methods Use in Medicinal Plants, Principle, Strength and Limitation. Med. Arom. Plants. 2015; 4:1-6. 
[28] N’Guessan K, Tra-Bi FH, Koné MW. Étude ethnopharmacologique de plantes antipaludiques utilisées en médecine traditionnelle chez les Abbey et Krobou d'Agboville (Côte d'Ivoire). Ethnopharmacologia. 2009; 44:42-50.

[29] Kambouche N, Merah B, Derdour A, Bellahouel S, Bouayed J, Dicko A, Younos C, Soulimani R. Hypoglycemic and antihyperglycemic effects of Anabasis articulate (Forssk) Moq (Chenopodiaceae), an Algerian medicinal plant. African J. Biotechnol. 2009; 8:5589-94.

[30] Koneri RB, Samaddar S, Ramaiah CT. Antidiabetic activity of triterpenoidsaponin isolate of MomordicacymbalariaFenzl. Indian J. Exp. Biol. 2014; 52:46-52.

[31] Velayutham R, Sankaradoss N, Nazeer-Ahamed KFH. Protective effect of tannins from Ficus racemosa in hypercholesterolemia and diabetes induced vascular tissue damage in rats. Asian Pacific J. Trop. Med. 2012:367-73.

[32] Hi CST, Howell SL. Effects of flavonoids on insulin secretion and calcium handling in rat islet of langerhans. J. Endocrinol. 1995:1-8.

[33] Waltner-Law ME, Wang XL, Law BK, Hall RK, Nawano M, Granner DK. Epigallocatechingallate, a constituent of green tea, represses hepatic glucose production. J. Biol. Chem. 2002; 277:34933-40.

[34] Shimizu M, Kobayashi Y, Suzuki M, Satsu H, Miyamoto Y. Regulation of intestinal glucose transport by tea catechins. Biofactors. 2000; 13:61-65.

[35] Li WL, Zheng HC, Bukuru J, De Kimpeb N. Natural medicines used in the traditional Chinese medical system for therapy of diabetes mellitus. J. Ethnopharmacol. 2004; 92:121.

[36] Medjdoub H, Selles C, Tabti B. Medicinal plants: a methodology for studying their anti-diabetic activity. Intern. J. Med. Pharm. Sci. 2013; 3:171-8.

[37] Sarkhail P, Rahmanipour S, Fadyevatan S, Mohammadirad A, Dehghan G, Amin G, Shafiee A, Abdollahi M. Antidiabetic effect of Phlomis anisodonta: Effects on hepatic cells lipid peroxidation and antioxidant enzymes in experimental diabetes. Pharmacol. Res. 2007; 56:261-66.
[38] Mogale MA, Lebelo SL, Thovhogi N, de Freitas AN, Shai LJ. $\alpha$-Amylase and $\alpha$-glucosidase inhibitory effects of Sclerocarya birrea [(A. Rich.) Hochst.] subspecies caffra (Sond) Kokwaro (Anacardiaceae) stem-bark extracts. African J. Biotechnol. 2011; 10:15033-39.

[39] Onal S, Timur S, Okutucu B. Inhibition of alpha-glucosidase by aqueous extracts of some potent antidiabetic medicinal herbs. Prep. Biochem. Biotechnol. 2005; 35:29-36.

[40] Gray AM, Flatt PR. Insulin-secreting activity of the traditional antidiabetic plant Viscum album (mistletoe). J. Endocrinol. 1999; 160:409-14.

[41] Henquin JC, Gilon P. Le contrôle de la sécrétion d'insuline par le glucose: signaux déclenchants et amplificateurs. Méd./sci. $1995 ; 11: 1235-42$.

[42] Ziaei A, Ramezani M, Wright L, Paetz C, Schneider B, Amirghofran Z. Identification of spathulenol in Salvia mirzayanii and the immunomodulatory effects. Phytother. Res. 2011; 25:557-62.

[43] Khanna K, Rizvi F, Chander R. Lipid lowering activity of phyllanthusnirui in hyperlipipemic rats. J. Ethnopharmacol. 2002; 82:19-22.

[44] Orskov H, Olsen TS, Wielsen K, Rafael OJ, Lundbeak KK. Kidney lesions in rats with severe long terme alloxan. Diabetologia. 1965; 1:172-9.

[45] Bouhouche I. Etude comparative de l'alloxane et de la streptozocine dans le diabète expérimental chez le rat blanc. Etude histologique du pancréas endocrine et la variation des paramètres sanguins. Mémoire de Magister en Biologie Animale. Université Constantine 1, Algérie; 2015.

[46] Babu PVA, Sabitha KS, Shyamaladevi CS. Therapeutic effect of green tea extract on oxidative stress in aorta and heart of streptozotocin diabetic rats. Chemico-Biol. Interact. 2006; 162:114-20 